\title{
PENGARUH WAKTU PEMBUNGAAN TERHADAP PRODUKSI BUAH DAN BENIH ACACIA HIBRID DI KEBUN PERSILANGAN Acacia mangium $\mathrm{X}$ Acacia auriculiformis
} The influence of Flowering time on the pod production and hybrid seed yield observed in the hybridization orchard of Acacia mangium $x$ Acacia auriculiformis

\author{
Sri Sunarti \\ Balai Besar Penelitian Bioteknologi dan Pemuliaan Tanaman Hutan \\ Jl. Palagan Tentara Pelajar Km. 15, Purwobinangun, Pakem, Sleman, Yogyakarta 55582 \\ Telp. (0274) 895954, 896080, Fax. (0274) 896080
}

Naskah masuk : 29 Maret 2011 - Naskah diterima : 2 Agustus 2011

\begin{abstract}
Observation of seed production and hybrid seed yield were assessed in a hybridization orchard of Acacia mangium $x$ Acacia auriculiformis on the first and second flowering season. The hybridization orchard was established in 2006 using 6 selected plus trees from the first-generation of progeny test of A. mangium and 12 selected plus trees from the first-generation of progeny test of A. auriculiformis. Crosses were conducted using 2 spikes for each cross. Based on synchronisation in flowering time, 6 and 17 crossing combinations were made resulting in 23 and 89 hybrid families in the first and second flowering seasons respectively. The average number of pods and seeds in the first flowering season were $1.9 \mathrm{pods} / \mathrm{spike}$ and 2.0 soundseeds/pod respectively, while those in the second flowering time were increased to $2.6 \mathrm{pods} / \mathrm{spike}$ and 2.4 soundseeds/pod respectively. The percentage of poorseeds almost the same on the first and second flowering seasons, namely $28.7 \%$ and $32.0 \%$ respectively. Verification using SCAR marker indicated that almost all of the collected seeds were hybrid seeds.
\end{abstract}

Key Words : Acacia hybrid, Acacia mangium, A. auriculiformis, controlled pollination

\begin{abstract}
ABSTRAK
Pengamatan produksi buah dan benih Acacia hibrid pada pembungaan pertama dan kedua dilakukan di kebun persilangan Acacia mangium x A. auriculiformis, B2PBPTH Yogyakarta. Kebun persilangan dibangun pada tahun 2006 menggunakan 6 pohon induk terpilih dari plot uji keturunan F-1 $A$. mangium dan 12 pohon induk terpilih dari plot uji keturunan F-1 A. auriculiformis. Berdasarkan sinkronisasi pembungaan fase pertama dan kedua, telah dilakukan sebanyak 6 dan 17 kombinasi persilangan $A$. mangium x A. auriculiformis. Sebanyak 23 dan 89 persilangan dengan metode anther tanpa emaskulasi telah dilakukan pada pohon induk betina $A$. mangium. Rata-rata produksi buah dan benih bernas hibrid pada pembungaan pertama berturut-turut sebanyak 1,9 polong/malai dan 2 biji bernas/polong, sedangkan pada pembungaan kedua meningkat sebesar 2,6 polong/malai dan 2,4 biji bernas/polong. Rata-rata persentase benih kosong tidak berbeda jauh antara pembungaan tahun pertama dan kedua. Verifikasi menggunakan penanda molekuler SCAR terhadap benih hibrid yang dihasilkan menunjukkan bahwa hampir semua benih adalah hibrid.
\end{abstract}

Kata Kunci : Benih hibrid, Acacia mangium, A. auriculiformis, penyerbukan terkendali 


\section{PENDAHULUAN}

\section{a. Latar Belakang}

Hibrid Acacia (Acacia mangium x A. auriculiformis) dapat diperoleh secara alami maupun secara buatan. Hibrid Acacia alami pertama kali dijumpai di Malaysia pada tahun 1970 pada pertanaman perindang jalan. Acacia hibrid buatan dapat diperoleh dengan melakukan penyerbukan terkendali atau menanam secara bersama-sama dengan jarak yang cukup dekat (Ibrahim, 1993).

Beberapa tulisan melaporkan bahwa hibrid Acacia sering mempunyai sifat heterosis positif (hybrid vigour), yaitu pertumbuhannya di atas rata-rata kedua tetuanya dan mempunyai ketahanan terhadap serangan penyakit serta mampu beradaptasi pada berbagai kondisi lingkungan (Kijkar, 1992; Ibrahim, 1993; Nikles, 1998; Kha, 2001). Lebih lanjut dilaporkan bahwa hibrid Acacia mempunyai batang lurus seperti $A$. mangium dan kemampuan meluruhkan cabang alami (selfpruning) yang baik seperti $A$. auri- culiformis serta sifat-sifat kayu yang sesuai untuk bahan baku pembuatan pulp (Kha, 2001).

Berbagai penelitian untuk memperoleh benih hibrid Acacia telah dilakukan (Rufelds, 1988; Sedgley et al., 1991; Gan dan Sim, 1991). Salah satu penelitian tentang produksi benih hibrid Acacia secara alami dilaporkan mempunyai tingkat produksi benih sebesar 0,7-21,7\% (Wickneswari dan Norwati, 1991). Beberapa kendala dalam memperoleh benih hibrid Acacia secara alami, antara lain berkaitan dengan sinkronisasi waktu pembungaan dan adanya inkompatibilitas putik dan serbuk sari. Upaya untuk memperoleh benih hibrid Acacia secara buatan juga telah dilakukan, namun demikian masih terdapat kendala dalam proses emaskulasi, karena ukuran kuntum bunga sangat kecil (Sedgley et al., 1991).

\section{b. Tujuan}

Tujuan dari penelitian ini adalah untuk mengetahui perbedaan fenologi pembungaan dan

Tabel 1. Data provenans pohon induk (klon) A. mangium dan A. auriculiformis di kebun persilangan B2PBPTH, Yogyakarta.

\begin{tabular}{|c|c|c|}
\hline Jenis & \begin{tabular}{|c|} 
No. \\
Klon
\end{tabular} & Informasi seedlot dan provenansi \\
\hline \multirow[t]{6}{*}{ A. mangium } & 28 & 17701-GFD00003 Claudie R \& Iron RA, AUS \\
\hline & 43 & 17702-GJM841 Pascoe R, AUS \\
\hline & 44 & 17946-GJM1100 Claudie R, AUS \\
\hline & 46 & 17701-GJM2359 Claudie R \& Iron RA, AUS \\
\hline & 49 & 17946-GJM1105 Claudie R, AUS \\
\hline & 51 & 17701-GFD00003 Claudie R \& Iron RA, AUS \\
\hline \multirow[t]{12}{*}{ A. auriculiformis } & 02 & 17941-JSL 350 Kennedy River, AUS \\
\hline & 03 & 16608-BVG 01295 Bandabern of Bulla, WP, PNG \\
\hline & 04 & 17553_KN 000013 Bensbach, WP, PNG \\
\hline & 05 & 18247-JSL, 361 Wenlock River, AUS \\
\hline & 06 & 17996-BH 14069 Boggy Creek, AUS \\
\hline & 07 & 17705-GJM 00889 Olive River, AUS \\
\hline & 08 & 17553_KN 000086 Bensbach, WP, PNG \\
\hline & 10 & 18601-BVG 01231 Morehead R Rouku WP, PNG \\
\hline & 11 & 17559-KN 000029 Bensbach WP,PNG \\
\hline & 12 & 18601-47R Orchard Melville Int, QLD \\
\hline & 13 & 17559-KN 000016 Bensbach, PNG \\
\hline & 14 & 17961-GJM 1048 Olive River, QLD \\
\hline
\end{tabular}


produksi benih Acacia hibrid pada musim pembungaan tahun pertama dan tahun kedua.

\section{BAHAN DAN METODE}

\section{a. Kebun Persilangan Acacia}

Kebun persilangan Acacia dibangun di Balai Besar Penelitian Bioteknologi dan Pemuliaan Tanaman Hutan (B2PBPTH) Yogyakarta pada tahun 2006. Terdapat 6 pohon induk terpilih dari hasil uji keturunan F-1 A. mangium dan 12 famili pohon induk terpilih dari hasil uji keturunan F-1 A. auriculiformis, data provenans masing-masing pohon induk disajikan dalam Tabel 1. Masingmasing klon dari pohon induk dikoleksi melalui teknik cangkok.

Klon yang telah dikoleksi selanjutnya ditanam di dalam kebun persilangan dengan pola tanam 1 klon $A$. mangium dikelilingi 4 klon $A$. auriculiformis dengan jarak tanam $3 \mathrm{~m} \times 3 \mathrm{~m}$ (Gambar 1).

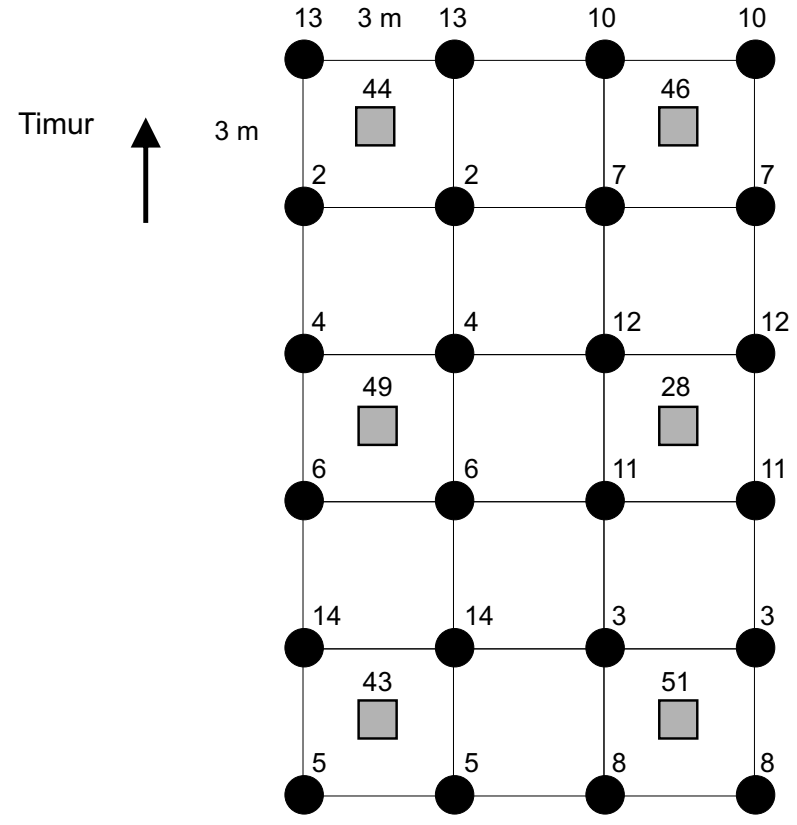

Keterangan: $=$ A. mangium, $\square=$ A. Auriculiformis 2-13=nomor klon A.auriculiformis, 28-51= nomor klon $A$. mangium

Gambar 1. Desain pola tanam di kebun persilangan Acacia

\section{b. Observasi Fenologi Pembungaan}

Informasi fenologi pembungaan dilakukan untuk menentukan kelimpahan bunga dan waktu sinkronisasi pembungaan. Observasi dilakukan

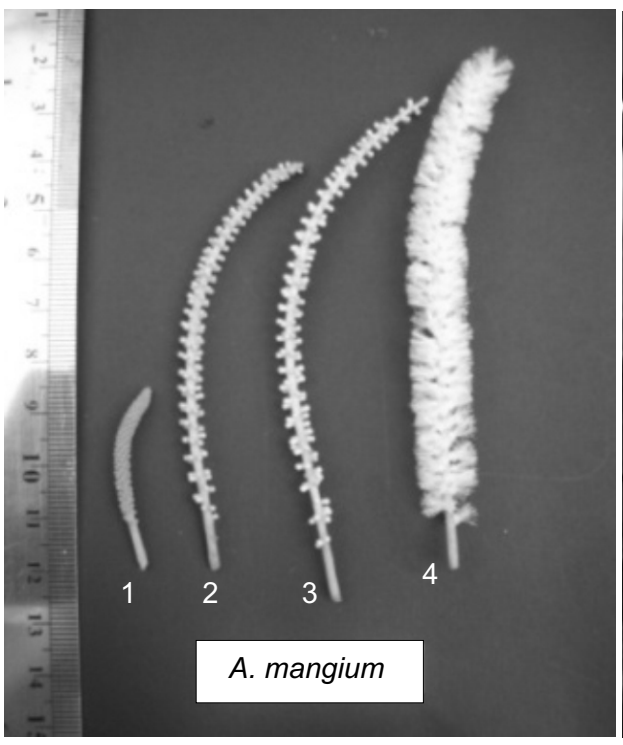

(a)

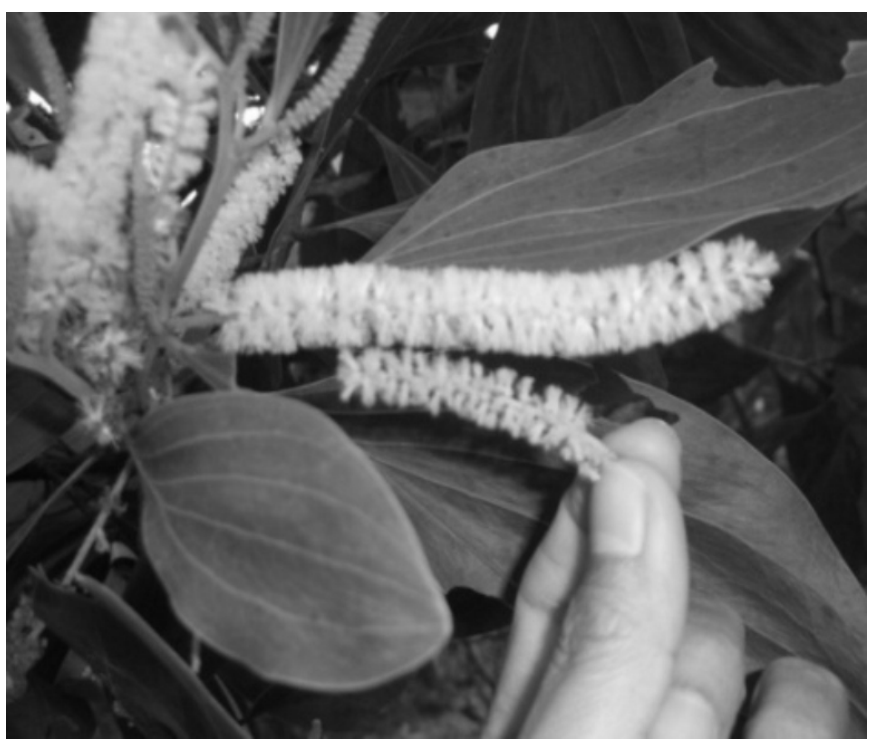

(b)

Gambar 2. Tahapan pembungaan A. mangium (a) : kuncup kecil/small bud (1), kuncup besar/big bud (2), kuncup siap mekar (3), dan bunga mekar sempurna/anthesis (4). Proses penyerbukan A. mangium $\mathrm{x}$ A. ariculiformis dengan metode anther (direct method) tanpa emaskulasi (b). 
dengan mencatat kelimpahan bunga siap mekar (Gambar 2.a-3) setiap 10 hari sekali pada setiap klon pada kedua jenis. Kelimpahan bunga siap mekar ditentukan dengan cara skoring 0-3 (Ibrahim dan Awang, 1991), yaitu $0=$ tidak ada bunga siap mekar, 1 = sedikit (jumlah bunga siap mekar pada $1 / 3$ bagian tajuk pohon), 2 = sedang (jumlah bunga siap mekar pada $2 / 3$ bagian tajuk pohon), 3 = banyak (jumlah bunga siap mekar hampir pada seluruh tajuk pohon). Informasi fenologi pembungaan selanjutnya digunakan untuk memperkirakan waktu bunga akan mekar sempurna dan sinkronisasi waktu pembungaan antar klon.

\section{c. Penyerbukan Silang dan Koleksi Benih Hibrid}

Berdasarkan data fenologi pembungaan (sinkronisasi pembungaan) selanjutnya disusun kombinasi persilangan (Gambar 3). Penyerbukan silang dilakukan terhadap klon yang mempunyai waktu pembungaan bersamaan. Penyerbukan dilakukan dengan metode anther atau direct method, yaitu tanpa emaskulasi, dalam hal ini $A$. mangium sebagai induk betina dan $A$. auriculi- formis sebagai induk jantan. Tahapan-tahapan penyerbukan terkendali sampai dengan koleksi benih adalah sebagai berikut:

1. Memilih kuncup bunga $A$. mangium yang telah siap mekar berwarna kuning (Gambar 2.a-3) untuk diisolasi dengan cara dikerudungi menggunakan kantong penyerbukan;

2. Setelah bunga mekar (1-2 hari) kantong penyerbukan dibuka, malai bunga yang belum mekar sempurna dibuang sehingga hanya bunga mekar sempurna yang tertinggal;

3. Bunga kemudian diserbuki dengan serbuk sari A. auriculiformis dengan cara mengoleskan malai secara cara langsung pada bunga $A$. mangium (Gambar 2.b);

4. Bunga yang telah diserbuki kemudian dikerudungi kembali dan diberi label sesuai dengan nomor induk tanaman yang disilangkan serta tanggal penyerbukan;

5. Kantong penyerbukan kemudian dibuka kembali setelah 3-4 hari;

6. Setelah kantong penyerbukan dibuka, perkembangan bunga menjadi polong masak diamati setiap 2 hari sekali;

\begin{tabular}{|l|c|c|c|c|c|c|}
\hline \begin{tabular}{l|l} 
KA u \\
오 Am
\end{tabular} & $\begin{array}{l}\text { Klon } \\
\text { no.10 }\end{array}$ & $\begin{array}{c}\text { Klon } \\
\text { no.11 }\end{array}$ & $\begin{array}{c}\text { Klon } \\
\text { no.12 }\end{array}$ & $\begin{array}{c}\text { Klon } \\
\text { no.13 }\end{array}$ & $\begin{array}{c}\text { Klon } \\
\text { no. 17 }\end{array}$ & $\begin{array}{c}\text { Klon } \\
\text { no.02 }\end{array}$ \\
\hline Klon no. 28 & $\mathbf{X}$ & $\mathbf{X}$ & $\mathbf{X}$ & $\mathbf{X}$ & $\mathbf{X}$ & $\mathbf{X}$ \\
\hline Klon no. 46 & $\mathbf{X}$ & $\mathbf{X}$ & $\mathbf{X}$ & $\mathbf{X}$ & $\mathbf{X}$ & $\mathbf{X}$ \\
\hline Klon no. 43 & $\mathbf{X}$ & $\mathbf{X}$ & $\mathbf{X}$ & $\mathbf{X}$ & $\mathbf{X}$ & $\mathbf{X}$ \\
\hline Klon no. 44 & $\mathbf{X}$ & $\mathbf{X}$ & $\mathbf{X}$ & $\mathbf{X}$ & $\mathbf{X}$ & $\mathbf{X}$ \\
\hline Klon no. 49 & $\mathbf{X}$ & $\mathbf{X}$ & $\mathbf{X}$ & $\mathbf{X}$ & $\mathbf{X}$ & $\mathbf{X}$ \\
\hline Klon no. 51 & $\mathbf{X}$ & $\mathbf{X}$ & $\mathbf{X}$ & $\mathbf{X}$ & $\mathbf{X}$ & $\mathbf{X}$ \\
\hline
\end{tabular}

Gambar 3. Kombinasi persilangan Acacia mangium x A. ariculiformis yang mungkin dilakukan di kebun persilangan pada fase pembungaan kedua (tahun 2008). $\mathrm{Am}=$ Acacia mangium, $\mathrm{Au}=A$. ariculiformis 
7. Memanen polong yang telah masak dan menghitung jumlah polong dan biji yang dihasilkan pada setiap kombinasi persilangan.

\section{d. Identifikasi benih hibrid}

Untuk menentukan status hibrid benih yang dihasilkan, benih disemaikan dan diidentifikasi menggunakan penanda morfologi dengan metode Rufelds (1988) yang telah disederhanakan oleh Gan dan Sim (1991) (Gambar 4) dan diverifikasi dengan penanda molekuler SCAR. Semai akan dinyatakan hibrid Acacia apabila hasil analisis DNA menghasilkan pola pita (banding pattern) dengan ukuran $900 \mathrm{pb}$ (pasangan basa) dan 400 pb. Penanda morfologi yang digunakan didasarkan pada perkembangan taksonomi daun, yaitu dimulai sejak munculnya daun once-pinnate sampai dengan munculnya filodia (Gambar 5). Semai hibrid Acacia mangium x A. Auriculiformis ditandai dengan jumlah daun bi-pinnate, dan ada tidaknya daun 4-pinnate serta jumlah daun pinnatus.

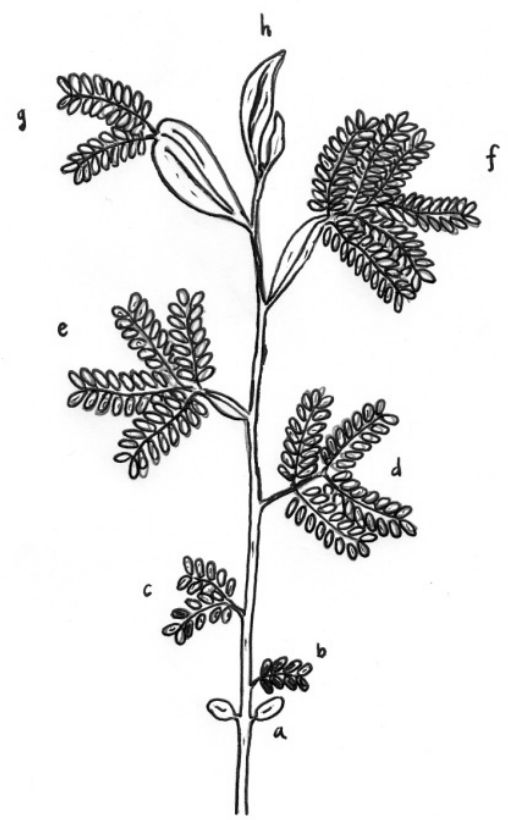

Gambar 5. Taksonomi semai A. mangium (Rufeld, 1988): (a) kotiledon, (b) Once-pinate, (c) bi-pinate, (d) 4-pinate, (e) filodia + 4-pinate, (f) filodia + 6-pinate pinate (g) filodia +2 - pinate, $(\mathrm{h})$ filodia.

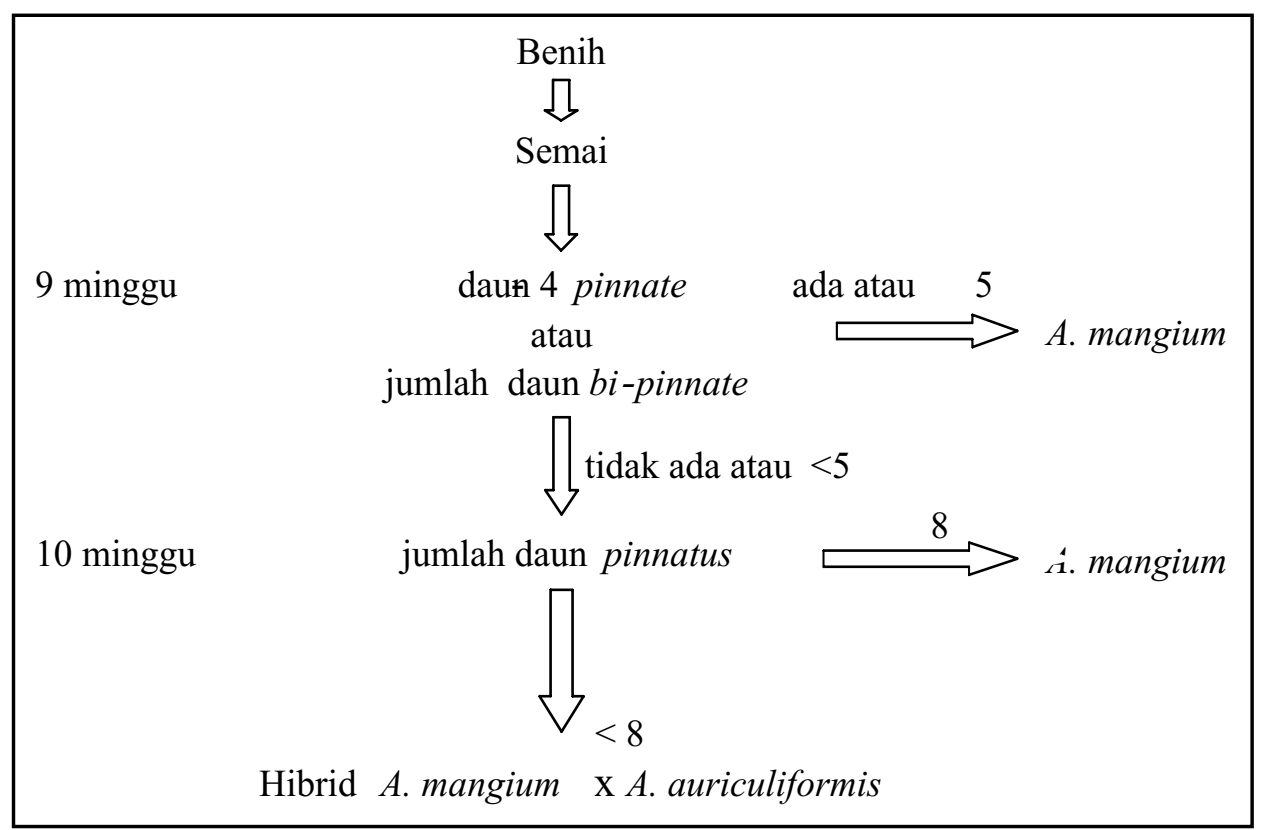

Gambar 4. Diagram metode Rufelds (1988) untuk mengidentifikasi semai hibrid A. mangium dan $A$. auriculiformis dengan $A$. mangium sebagai pohon induk betina yang telah disederhanakan oleh Gan dan Sim,1991. 


\section{HASIL DAN PEMBAHASAN}

\section{a. Fenologi Pembungaan}

Hasil observasi terhadap waktu pembungaan pada musim pembungaan pertama (tahun 2007) terdapat 6 klon yang berbunga (2 klon $A$. mangium dan 4 klon $A$. auriculiformis) pada bulan Mei-September dengan puncak pembungaan pada bulan Mei, sedangkan pada musim pembungaan kedua (tahun 2008) terdapat 12 klon (6 klon A. mangium dan 6 klon A. auriculiformis) pada bulan Januari-Juni dengan puncak pembungaan pada bulan Januari. Pengamatan kelimpahan bunga siap mekar pada fase pembungaan pertama menunjukkan bahwa semua klon $A$. mangium telah berbunga dengan variasi periodisitas antara bulan Mei-September. Pada klon A. auriculiformis hanya terdapat 4 klon yang telah berbunga dengan variasi periodisitas yang sama dengan $A$. mangium. Dari semua klon yang berbunga, waktu pembungaan yang sinkron hanya terjadi pada 2 klon A. mangium (Am 28 dan Am 46) dan 4 klon A. auriculiformis (Au 1013). Pada pembungaan kedua, musim berbunga terjadi lebih awal 2 bulan, yaitu bulan Januari September dengan puncak pembungaan pada bulan Januari. Pada musim pembungaan kedua ini semua klon $A$. mangium berbunga, dan sebanyak 6 klon pada $A$. auriculiformis. Dari seluruh 12 klon yang berbunga tersebut, semua mempunyai waktu pembungaan yang sinkron dengan tingkat kelimpahan yang bervariasi dari sedikit sampai banyak.

Perbedaan waktu pembungaan dan kelimpahan jumlah bunga pada klon $A$. mangium maupun $A$. auriculiformis diduga disebabkan oleh faktor internal dan eksternal atau lingkungan tempat tumbuh. Faktor internal antara lain adalah faktor genetis dan hormonal/fitohormon (Opik dan Rolfe, 2005; Pallardy, 2008). Secara genetis kemungkinan terdapat perbedaan kemampuan dalam memproduksi bunga, sehingga terjadi kelimpahan bunga yg tidak sama antar klon, baik pada $A$. mangium maupun $A$. auriculiformis. Selain itu kemungkinan juga disebabkan oleh perbedaan sistem hormonal/fitohormon antar klon. Hormon yang paling berpengaruh terhadap proses pembungaan adalah hormon sitokinin berfungsi aktif dalam peningkatan energi metabolisme yang sangat diperlukan dalam proses pembentukan kuncup bunga (Opik dan Rolfe, 2005).

Selain faktor internal tersebut, faktor lingkungan juga sangat berpengaruh pada proses pembentukan bunga atau fase pertumbuhan reproduktif. Faktor lingkungan yang paling berpengaruh antara lain adalah suhu, cahaya, kelembaban dan ketersediaan unsur hara. Faktor lingkungan tempat tumbuh berupa suhu, kelembaban dan ketersediaan unsur hara pada klonklon $A$. auriculiformis dan A. mangium relatif sama kecuali cahaya, yaitu intensitasnya. Terdapat perbedaan intensitas cahaya pada klon yang ditanam di bagian tepi dan bagian tengah. Klon yang belum berbunga atau kelimpahan bunganya sedikit baik pada pembungaan pertama maupun kedua, sebagian besar merupakan klonklon yang mendapatkan sinar matahari dengan intensitas cahaya kurang optimal karena ternaungi oleh tegakan pohon lain yang tumbuh berdekatan yang berukuran tajuk lebih besar. Kecilnya intensitas cahaya yang diterima daun menyebabkan terhambatnya proses inisiasi pembungaan berkaitan dengan rendahnya tingkat 
fotosintesis yang terjadi (Sedgley, 1985). Terjadinya pergeseran panjang musim penghujan dan musim kemarau akan menyebabkan juga pergeseran musim pembungaan karena menyebabkan terjadinya perubahan lingkungan terutama lama penyinaran matahari dan intensitas cahaya yang akan mempengaruhi proses diferensiasi sel-sel primordia bunga (Pallardy, 2008). Proses diferensiasi akan berkurang dengan berkurangnya lama penyinaran dan intensitas cahaya karena menyebabkan berkurangnya suhu udara.

\section{b. Produksi Polong/Buah dan Benih}

Berdasarkan data sinkronisasi waktu pembungaan, selanjutnya dilakukan persilangan dengan $A$. mangium sebagai pohon induk betina dan $A$. auriculiformis sebagai induk jantan. Jumlah bunga yang dapat disilangkan pada musim pembungaan pertama dan kedua relatif berbeda, demikian pula polong dan benih yang dihasilkan. Kombinasi persilangan yang dapat dilakukan dan hasil observasi terhadap produksi polong dan benih pada musim pembungaan pertama dan kedua berturut-turut sebanyak 6 kombinasi dan 17 kombinasi. Hasil produksi polong dan benih pada masing-masing pembungaan disajikan dalam Tabel 3 .
Produksi polong hibrid Acacia pada fase tahun pertama ini masih relatif sedikit dibandingkan dengan pembungaan kedua, yaitu berturutturut sebesar rata-rata sebanyak 1,9 polong per malai dan 4,5 polong per malai. Selain produksinya masih sedikit, rata-rata benih bernas per polong yang dihasilkan pada pembungaan pertama juga lebih kecil dibandingkan dengan pembungaan kedua, berturut-turut 2 dan 4,4 biji bernas per polong. Namun demikian jumlah presentase benih kosong yang dihasilkan pada pembungaan pertama relatif lebih sedikit dibandingkan dengan pembungaan kedua, yaitu berturut-turut $28,7 \%$ dan $32,0 \%$. Klasifikasi benih bernas dan benih kosong dilakukan berdasarkan morfologinya; benih bernas ditandai dengan ciri morfologi biji keras dan berisi serta kulit luarnya mengkilap dan halus sedangkan biji kosong ditandai dengan ciri morfologi biji lembek, gepeng dan kulit luarnya keriput dan kusam (Gambar 6).

Rendahnya produksi polong dan benih hibrid Acacia pada pembungaan pertama dibandingkan dengan pembungaan kedua disebabkan antara lain karena klon yang berbunga dan mempunyai waktu sinkronisasi waktu pembungaan relatif masih sedikit. Dengan sedikitnya kuntum bunga yang dapat disilangkan secara langsung akan

Tabel 3. Produksi polong/buah dan benih Acacia hibrida (A. mangium $\mathrm{x}$ A. auriculiformis ) di kebun persilangan pada musim pembungaan pertama (tahun 2007) dan pembungaan kedua (tahun 2008).

\begin{tabular}{|l|c|c|c|c|c|c|}
\hline \multirow{2}{*}{ Pembungaan } & \multicolumn{6}{|c|}{ Jumlah } \\
\cline { 2 - 7 } & $\begin{array}{c}\text { Kombinasi } \\
\text { persilangan }\end{array}$ & Persilangan & Malai & Polong & $\begin{array}{c}\text { Biji } \\
\text { bernas }\end{array}$ & $\begin{array}{c}\text { Biji } \\
\text { kosong }\end{array}$ \\
\hline $\begin{array}{l}\text { Pertama } \\
(2007)\end{array}$ & 6 & 23 & 46 & 86 & 176 & 71 \\
\hline $\begin{array}{l}\text { Kedua } \\
(2008)\end{array}$ & 17 & 89 & 137 & 606 & 3.198 & 1.510 \\
\hline
\end{tabular}




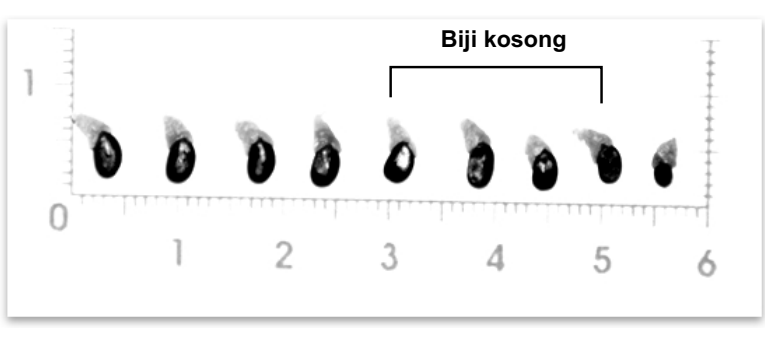

Gambar 6. Benih kosong dan bernas pada hibrid acacia (A. mangium $\times$ A . auriculiformis) dalam 1 polong hasil persilangan antara pohon induk betina $A$. mangium dengan nomor klon 28 dengan pohon induk jantan $A$. auriculiformis dengan klon 11.

berpengaruh pada polong dan benih yang diproduksi. Selain itu kebanyakan kuntum bunga betina $A$. mangium per malai pada pembungaan pertama relatif rendah yaitu sebesar $36,1 \%$, sehingga malai lebih didominasi oleh kuntum bunga jantan (staminate flower) (Sunarti, 2009). Rendahnya bunga betina pada malai diduga disebabkan oleh karena secara fisiologis tanaman belum dewasa, sehingga pertumbuhan organorgan reproduksi juga belum sempurna. Keterbatasan jumlah bunga betina akan menyebabkan terbatasnya jumlah putik yang dapat diserbuki sehingga biji yang dihasilkan juga relatif sedikit.

Persentase benih bernas pada pembungaan pertama dan kedua tidak berbeda jauh, yaitu berturut-turut sebesar $71,2 \%$ dan $68,3 \%$ dari seluruh benih yang diproduksi. Produksi benih bernas diduga tidak dipengaruhi oleh musim pembungaan, akan tetapi lebih dipengaruhi oleh kompatibilitas antara putik dan serbuksari. Selain itu dimungkinkan disebabkan juga oleh perbedaan tingkat reseptifitas antara putik $A$. mangium dan serbuk sari $A$. auriculiformis yang menyebabkan proses pembuahan tidak sempurna atau terhambat, sehingga menghasilkan biji kosong.
Kondisi seperti ini biasanya terjadi pada penyerbukan silang antar spesies (Chaudary, 1984).

Lebih lanjut Chaudary (1984) menjelaskan bahwa rendahnya produksi benih bernas erat kaitannya dengan tipe serbuk sari yang merupakan serbuk sari majemuk (polyads). Karena bentuk serbuk sari majemuk berbentuk bikonvek dengan bagian tengah menebal, maka posisi serbuk sari pada saat menempel pada permukaan putik yang berbentuk mangkuk juga menentukan jumlah butiran serbuk sari yang mampu berkecambah. Apabila posisi serbuk sari horisontal, maka butiran-butiran serbuk sari yang menempel pada permukaan putik dan berkesempatan berkecambah adalah setengah dari seluruh butiran serbuk sari (Kenrick dan Knox, 1982). Serbuk sari akan berkecambah apabila serbuksari menempel pada permukaan kepala putik yang telah mengeluarkan exudate.

\section{c. Verifikasi Hibrid Acacia}

Verifikasi dilakukan untuk mengetahui tingkat ketepatan penanda morfologi yang digunakan untuk mengidentifikasi semai hibrid Acacia. Verifikasi dilakukan menggunakan

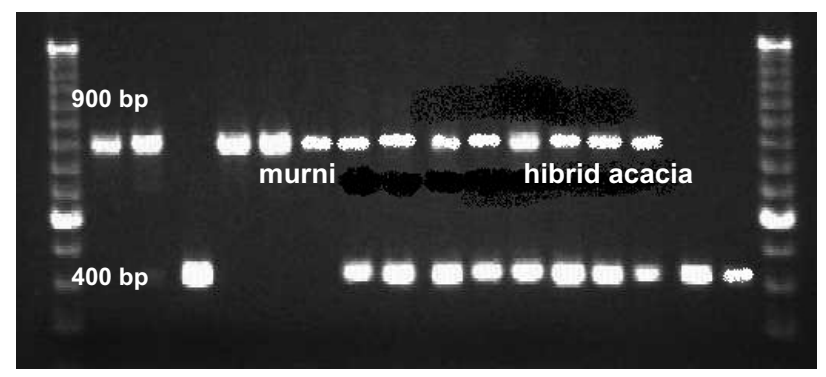

Gambar 7. Pola pita hasil elektroforesis gel menggunakan agarose $1,2 \%$ dengan pewarnaan menggunakan ethidium bromide dengan primer R01. Pita dengan ukuran $400 \mathrm{pb}$ adalah A auriculiformis, $900 \mathrm{pb}$ adalah A. mangium, dan pita dengan ukuran 400 $\mathrm{pb}$ dan $900 \mathrm{pb}$ adalah hibrid Acacia (Sunarti, 2007). 
penanda molekuler SCAR (Sequenced Characterized Amplified Region), yaitu penanda molekuler yang dikembangkan dari spesies spesifik A. mangium dan A. auriculiformis (Widyatmoko, 2006). Pola pita (banding pattern) hasil elektroforesis pada hibrid Acacia menunjukkan pita dengan ukuran $400 \mathrm{pb}$ dan $900 \mathrm{pb}$, apabila hanya terdapat satu pita saja, maka bukan merupakan hibrid Acacia (Gambar 7).

Hasil verifikasi terhadap 48 sampel semai hibrid Acacia yang telah diidentifikasi menggunakan penanda morfologi, 44 merupakan hibrid Acacia, 1 A. mangium dan 3 sampel pola pitanya tidak muncul. Hasil verifikasi menunjukkan bahwa penanda morfologi berupa penanda taksonomi anak daun efektif dan efisien untuk mengenali hibrid Acacia pada tingkat semai dengan tingkat ketepatan sebesar 91,7\%. Hasil verifikasi juga menunjukkan bahwa penyerbukan buatan pada $A$. mangium dan $A$. auriculiformis menggunakan metode anther efisien untuk menghasilkan benih hibrid Acacia dengan kemungkinan terjadinya penyerbukan sendiri (selfing) sebesar $2 \%$.

\section{KESIMPULAN}

Dari hasil penelitian ini dapat diambil beberapa kesimpulan sebagai berikut:

1. Kelimpahan bunga dan sinkronisasi waktu pembungaan antara klon $A$. mangium dan $A$. auriculiformis pada fase pertama pembungaan (umur 1 tahun) di kebun persilangan masih relatif cukup rendah dibandingkan pada pembungaan kedua.
2. Terdapat pergeseran waktu pembungaan pada tahun pertama dan tahun kedua musim pembungaan, yaitu berturut-turut Mei-September 2007 dan Januari-September 2008.

3. Produksi polong dan benih hibrida pada pembungaan pertama relatif lebih kecil dibandingkan pada pembungaan kedua.

4. Beberapa kondisi yang menyebabkan rendahnya produksi buah dan benih hibrid pada pembungaan pertama (tahun pertama) antara lain rendahnya kelimpahan malai bunga $A$. mangium dan sedikitnya jumlah kuntum bunga (floret) betina pada setiap malai dan waktu pembungaannya lebih pendek.

5. Faktor yang menyebabkan terjadinya benih kosong pada pembungaan pertama maupun kedua antara lain adalah adanya inkompatibilitas dan perbedaan tingkat reseptifitas antara putik $A$. mangium dan serbuk sari $A$. auriculiformis.

\section{DAFTAR PUSTAKA}

Chaudary, R.C. 1984. Introduction to plant breeding. Oxford \& IBH Publishing Co. New Delhi. Bombay. Calcuta. pp 40-41.

Gan, E. dan Sim, B.L. 1991. Nursery identification of hybrid seedlings in open plots. In: Carron, L.T and Aken, K.M. (eds). Breeding technologies for tropical Acacias. ACIAR Proceeding. No. 37. Canberra.pp. 76-85.

Ibrahim, Z. 1991. dan Awang, K. Flowering and fruiting phenology of Acacia mangium and Acacia auriculiformis in Peninsular Malaysia. In: Carron, L.T. dan K.M. Aken (eds). Breeding technologies for tropical 
Acacias. ACIAR Proceeding No. 37. Sedgley, M., J. Harbard, R.M. Smith, dan R.

Canberra. pp.45.

Ibrahim, Z. 1993. Reproductive Biology. In:

Awang, K. and Taylor, D. (eds). Acacia mangium. Growing and utilization. Winrock International and the Food and Agriculture Organization of the United Nations. Bangkok.Thailand.pp. 21-30.

Kha, L.D. 2001. Studies on the use of natural hybrids between Acacia mangium and Acacia auriculiformis in Vietnam. Agriculture Publising House. Hanoi. pp. 510 .

Kramer, P.J., dan Kozlowski, T.T. 1960. Physiology of Tree. New York. MeGrawHill.

Kenrick, J. dan Knox, R.B.1982. Function of the Polyad in Reproduction of Acacia. Annals of Botany. No. 50. Australia. pp. 721-727.

Nikles, D.G., C.E. Hardwood, K.J. Robson, P.C. Pomroy. dan R.J. Keenan. 1998. Management and use of ex situ genetic resources of some tropical Acacias species in Queensland. In: J.W. Turnbull, H.R. Cropton dan K. Pinyopusarerk (eds). Developments in Acacias planting. ACIAR Proceedings. No. 82. Canberra. Australia. pp. 184-196.

Opik, H. dan S.A. Rolfe. 2005. The Physiology of Flowering Plants.Cambridge.

Pallardy, S.G. 2008. Physiology of Woody Plants.Third Edition.Elsevier.London.

Rufeld, C.W. 1988. Acacia mangium and Acacia auriculiformis and hybrid $A$. mangium x $A$. auriculiformis. Seedling Morphology study. Forest Research Centre Publication. No. 41. Sabah. Malaysia.
Wickneswary. 1991. Development of Hybridisation Techniques for Acacia mangium x Acacia auriculiformis In: Carron,L.T. and Aken, K.M. (eds). Breeding technologies for tropical Acacias. Proceeding ACIAR. No. 37. Canberra. pp.63-69.

Sunarti, S. 2007. Identifikasi Benih dan Semai Hibrid Acacia mangium X Acacia auriculiformis, Acacia auriculiformis $\mathrm{x}$ Acacia mangium Menggunakan Penanda Morfologi dan Penanda Molekuler SCAR. Thesis pada sekolah pasca sarjana Universitas Gadjah Mada,Yogyakarta.

Sunarti, S. 2009. Produksi buah dan benih Acacia hibrid di kebun persilangan (Acacia mangium $\mathrm{x}$ A. auriculiformis). Jurnal Pemuliaan Tanaman Hutan. ISSN : 16937147. Vol. 3, Juli 2008.

Wickneswari, R dan Norwati,M. 1991. Pod Production and Hybrid Seed Yield in Acacia mangium x Acacia auriculiformis In: Breeding technologies for tropical Acacias. L.T. Carron dan K.M. Aken (eds.). ACIAR Proceeding. No. 37. Canberra. pp.57-60.

Widyatmoko, A.Y.P.B.C dan Shiraishi, S. 2003. Spesies-Specific RAPD Marker for Identification of $A$. mangium, $A$. auriculiformis and Their Hybrid. Kyushu Journal Forest Resources. No. 56. Kyushu. Japan. 